\title{
Formation and Release of Secretory Granules during Mitosis in the Anterior Pituitary Gland
}

\author{
Kazumasa Kurosumi \\ Department of Morphology (Prof. K. Kurosumi), Institute of Endocrinology, Gunma University, \\ Maebashi, Japan
}

Received May 14, 1979

Summary. Electron microscopic images indicating exocytosis of secretory granules were obtained in rat prolactin cells undergoing mitosis at the estrus in the female reproductive cycle. Immature secretory granules looking like small cored vesicles were found among chromosomes and microtubules of the mitotic spindle. Golgi apparatus was fragmented and its small elements mostly consisting of vesicles were seen at the peripheral region of the cell. Rough endoplasmic reticulum was mostly vesiculated, but lamellar stacks were still recognized at the cell periphery. It is evident that fully differentiated cells of the anterior pituitary glands are capable of continuing the activity of secretion, i.e., formation and release of secretory granules during mitosis.

Since Heidenhain (1911) a misunderstanding that the highly differentiated cells could not undergo mitosis has prevailed, and many authors claimed that only undifferentiated (embryonic) and dedifferentiated (tumor) cells could divide through mitosis (Peter, 1929; Cowdry, 1932; AbBott and Holtzer, 1966). In the adenohypophysis, however, some researchers as a result of light microscopy have been aware of the fact that fully differentiated secretory cells may multiply through mitosis (Allanson et al., 1969). By electron microscopy Kurosumi and Kobayashi (1966) in ACTH cells and Zambrano and DeIs (1970) in prolactin cells demonstrated mitotic figures in the cells containing secretory granules. The author also observed by electron microscopy many types of anterior pituitary cells undergoing mitosis, and demonstrated an ultrastructural feature of formation of immature secretory granules in the Golgi apparatus at the metaphase of mitosis in a growth hormone-producing cell (Kurosumi, 1971). However, no reports concerning the extrusion of secretory granules during mitosis have been published. In the course of further studies the author observed prolactin cells performing exocytotic release of mature secretory granules at the metaphase or anaphase of mitosis. This finding and related discussion will appear in this paper. 


\section{MATERIALS AND METHODS}

The pituitary glands of female rats of Wistar-Imamichi strain at various stages of estrous cycle were removed after decapitation. Samples of the anterior lobe cut into small pieces less than $1 \mathrm{~mm}^{3}$ were fixed with $2.5 \%$ glutaraldehyde adjusted to $\mathrm{pH} 7.2$ with $1 / 15 \mathrm{M}$ phosphate buffer for $2-3 \mathrm{hrs}$ and then postfixed with $2 \%$ osmium tetroxide with the same buffer for about $2 \mathrm{hrs}$. After dehydration with an ascending series of concentration of ethanol the specimens were embedded in a mixture of Epon and Araldite. Thin sections were made on a Porter-Blum ultramicrotome MT-2B and stained with uranyl acetate and lead citrate. Electron microscopy was carried out on a Hitachi $\mathrm{H}-700$ at the accelerating potential of $100 \mathrm{kV}$, and photographed at a magnification of 7,000 times and thereafter enlarged optically as desired.

\section{RESULTS}

Two mitotic prolactin cells were found in the anterior pituitary of an estrous female rat. They are situated in juxtaposition to each other. The prolactin cells are often localized near the blood capillary, but the exocytosis occurs not only on the surface facing the capillaries, but also on the cell surface to the ordinary intercellular space (Fig. 1). There is no relation between the spindle axis and the cell polarity in regard to the vascular pole of the cell.

Mature secretory granules are mostly pushed against the cell periphery by the mitotic figure, but some remained in the central cytoplasm among chromosomes and spindle tubules (Fig. 1,2). They are usually large in size and irregular in shape, but very small irregular granules and small or large regularly round granules are also observed (Fig. 1). Features of exocytosis are abundantly observed along the surface of the cell during mitosis (Fig. 1,2). A massive extrusion of several granules was also observed (Fig. 1).

Mitochondria are round or oval in most cases, but a few rod-like ones are also observed. Cisternae of the rough endoplasmic reticulum are mostly vesiculated but some are still elongate and arranged parallel to one another at relatively peripheral parts of the cell. Free ribosomes are abundant. The Golgi apparatus is fragmented and small Golgi elements are seen mostly in the cell periphery. There are stacks of a few vesicles, and flattened sacs are seldom observed (Fig. 1). Small cored vesicles which are thought to be the immature stage of granule formation are observed either adjacent to the Golgi elements or independently among chromosomes or spindle tubules (Fig. 1, 2).

Microtubules forming the mitotic spindle are attached to the chromosomes by the kinetochores on one hand, and on the other hand converge to the centrioles representing the spindle poles. These mitotic features are quite normal in every respect. The concomitant extrusion of secretory granules through the mechanism of exocytosis is unique in the dividing cells in the present observation. 


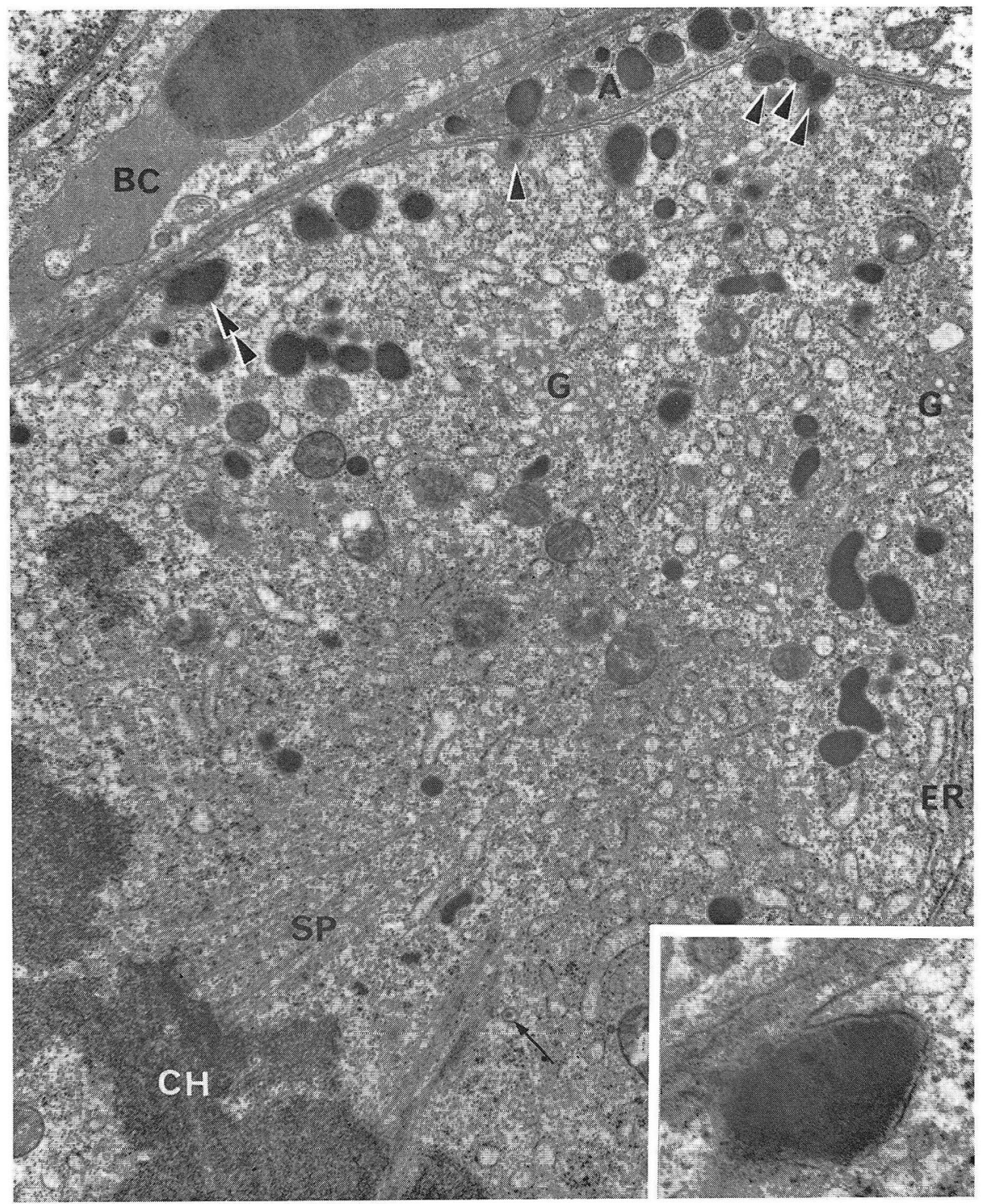

Fig. 1. $\Lambda$ prolactin cell of an estrous rat anterior pituitary undergoing mitosis. The cell abuts on the blood capillary $(B C)$. A slender process of another prolactin cell $(A)$ is inserted between the dividing cell and the blood capillary. Features of exocytosis (arrowheads) are observed along the cell border either facing the blood capillary or adjacent to another prolactin cell. At the upper right corner a massive extrusion is seen (triple arrowheads). A small immature granule (arrow) is seen near the spindle tubules (SP) which are attached to chromosomes $(\mathrm{CH})$. Dispersed Golgi elements $(G)$ consist of aggregated vesicles. Rough endoplasmic reticulum $(E R)$ in the periphery of the cell is lamellated. $\times 15,000$. The inset shows a high magnification view of extruding granule indicated by double arrowheads. $\times 50,000$ 


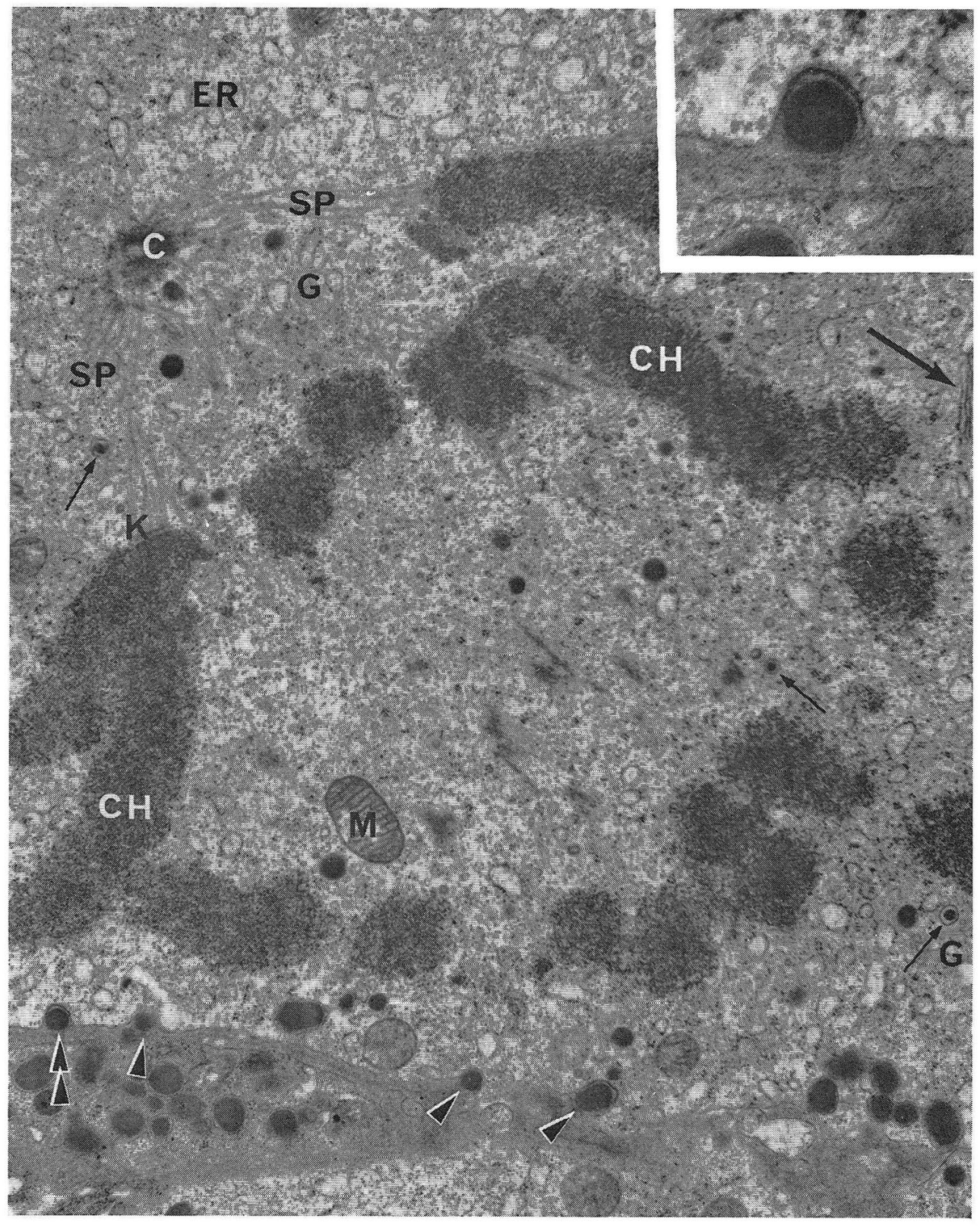

Fig. 2. A prolactin cell during mitosis found in the anterior pituitary of an estrous rat. The spindle tubules $(S P)$ converge to the centriole $(C)$ and the other ends terminate on the kinetochore $(K)$ of chromosomes $(\mathrm{CH})$. Immature secretory granules in a form of cored vesicles are observed in many places (small arrows). Golgi elements $(G)$ consist of vesicles. Rough endoplasmic reticulum $(E R)$ are mostly vesiculated but some are lamellated (large arrow). $M$ indicates mitochondria. Granule extrusion into the intercellular space through cxocytosis is seen at many points (arrowheads). $\times 15,000$. The inset shows a high magnification view of granule extrusion indicated by double arrowheads. $\quad \times 50,000$ 


\section{DISCUSSION}

Аввотт and Holtzer (1966) wrote that the cultured chondrocytes synthesizing chondroitin sulfate did not concurrently synthesize DNA and divide. This finding might support the notion that the fully differentiated cells lose the ability to divide through mitosis (HEIDENHAIN, 1911; RUSCH, 1954). However, many reports have been published indicating the possibility to undergo mitosis for well differentiated cells of various types of tissues such as adenohypophyseal cells (Allanson et al., 1969; Kurosumi and Kobayashi, 1966; Zambrano and Deis, 1970; Kurosumi, 1971), pancreatic islets (LiKe and CHick, 1969), smooth muscle cells (СовB and BenNetT, 1970), parotid gland (Redman and Sreebny, 1970), non-neoplastic melanocytes (Jimbow et al., 1975) and thyroid follicular cells (ZELIGS and WoLlman, 1979).

The presence of secretory granules in dividing cells is not a direct evidence of coexistence of secretory and mitotic activities at the same time in the same cell, because the secretory granules found in the mitotic cells might be produced a certain length of time before the beginning of mitosis. The features of new formation of immature secretory granules near the Golgi elements of dividing cells (REDMAN and SReebny, 1970; Kurosumi, 1971) might be a more powerful evidence. Furthermore, the present finding indicates exocytotic release of secretory granules during mitosis, and it may be one of the more convincing evidences of concomitance of secretion and mitosis.

As it is known that the serum content of prolactin is higher at estrus than at diestrus (SHino et al., 1972), the release of prolactin (granule extrusion) may probably be high in the estrus and it occurs even in the cells undergoing mitosis.

Acknowledgement. The author is indebted to Dr. Yasue Yukitake for his technical assistance in preparation of specimens.

\section{下垂体前葉に見られた有系分裂中の細胞における分泌果粒の形成と放出}

黒住一昌

発情期の䧳ラットの下垂体前葉プロラクチン産生細胞において，有系分裂中に分泌果粒が 開口放出される電子顕微鏡像をとらえた。微細な有芯小胞状を呈する未熟果粒が。染色体 の間，あるいは紡鍾微細管の付近に観察される。分裂に際しゴルジ装置は分断されるが， その要素は 主として小胞から成り, 細胞の辺縁部に存在する。粗面小胞体は大部分が小胞 化するが，細胞辺縁部には層板状の槽の集積も残存する．下垂体前葉の完全に分化した細 胞も有系分裂を行ない，その問も分泌機能すなわち分泌果粒の形成と放出を継続するこ とができる. 


\section{REFERENCES}

Abbott, J. and H. Holtzer: The loss of phenotype traits by differentiated cells. III. The reversible behavior of chondrocytes. J. Cell Biol. 28: 473-487 (1966).

Allanson, M., C. L. Foster and E. Cameron: Mitotic activity in the adenohypophysis of pregnant and lactating rabbits. J. Reprod. Fert. 19: 121-131 (1969).

Cobb, J. L. S. and T. Bennett: An ultrastructural study of mitotic division in differentiated gastric smooth muscle cells. Z. Zellforsch. 108: 177-189 (1970).

Cowdry, E. V.: The skin. In: (ed. by) E. V. Cowdry: Special cytology. Paul B. Hoeber, New York, 1932 (cited from Abbott, J. and H. Holtzer, 1966).

Heidenhain, M. : In: Plasma und Zelle. G. Fischer, Jena, 1911 (cited from Abbott, J. and H. Holtzer, 1966).

Jimbow, K., S. I. Roth, T. B. Fitzpatrik and G. Szabo: Mitotic activity in non-neoplastic melanocytes in vivo as determined by histochemical, autoradiographic, and electron microscope studies. J. Cell Biol. 66: 663-670 (1975).

Kurosumi, K. : Mitosis of the rat anterior pituitary cells: An electron microscope study. Arch. histol. jap. 33: 145-160 (1971).

Kurosumi, K. and Y. Kobayashi : Corticotrophs in the anterior pituitary gland of normal and adrenalectomized rats as revealed by electron microscopy. Endocrinology 78: 745-758 (1966).

Like, A. A. and W. L. Chick: Mitotic division in pancreatic beta cells. Science 163: 941-943 (1969).

Peter, K.: Zellteilung und Zelltätigkeit. Sechste Mitteilung der Einfluß einer Fütterung auf die Mitosenverteilung. Z. Zellforsch. 9: 129 (1929) (cited from Abbott, J. and H. Holtzer, 1966).

Redman, R. S. and L. M. Sreebny : Proliferative behavior of differentiating cells in the developing rat parotid gland. J. Cell Biol. 46: 81-87 (1970).

Rusch, H. P. : Carcinogenesis: A facet of living processes. Cancer Res. 14: 407-417 (1954).

Shiino, M., G. Williams and E. G. Rennels : Ultrastructural observation of pituitary release of prolactin in the rat by suckling stimulus. Endocrinology 90: 176-187 (1972).

Zambrano, D. and R. P. Deis : The adenohypophysis of female rats after hypothalamic oestradiol implants: An electron microscopic study. J. Endocrinol. 47: 101-110 (1970).

Zeligs, J. D. and S. H. Wollman: Mitosis in rat thyroid epithelial cells in vivo. 1. Ultrastructural changes in cytoplasmic organelles during the mitotic cycle. J. Ultrastr. Res. 66: 5377 (1979).

黒住一昌

$\mathbf{T} 371$ 前橋市昭和町

群馬大学内分泌研究所

形態学研究部
Prof. Kazumasa Kurosumi

Department of Morphology Institute of Endocrinology

Gunma University

371 Maebashi, Japan 